Walisongo: Jurnal Penelitian Sosial Keagamaan

Vol. 28 No. 2 (2020) pp. 249-266

DOI: $10.21580 /$ ws.28.2.6534

\title{
Women's Socio-Political Dynamics in Indonesian Literature
}

\author{
Wajiran Wajiran, ${ }^{1 *}$ Dani Fadillah ${ }^{2}$ \\ ${ }^{1,2}$ Universitas Ahmad Dablan, Yogyakarta, Indonesia
}

\begin{abstract}
Literary works have been believed to be media to spread ideas or ideology. This paper seeks to examine the images of women before Indonesia's Reformation Era as reflected in Ahmad Tohari's Bekisar Merah and after the Reformation Era as reflected in Ayu Utami's Saman. By employing qualitative modes of inquiry and theories in the sociology of literature, this study has shown that images of women before and after Indonesia's Reformation Era were depicted differently. Before Indonesia's Reformation Era, the image of women tended to be submissive in dealing with the socio-political dynamics, while after the Reformation Era in 1998, they were depicted as progressive and even rebellious. However, it is also important to notice that this difference indicated the writers' political and ideological preference in describing the women's position in Indonesian society in their era. The findings of this study support Gramsci's idea about ideological or cultural hegemony presented by literary work.
\end{abstract}

Karya sastra diyakini dapat menjadi media penyebaran ide-ide atau ideologi. Penelitian ini berusaha menguak potret perempuan sebelum Era Reformasi yang tercermin dalam Novel Bekisar Merah karya Ahmad Tohari dan setelah Era Reformasi yang tercermin dalam Novel Saman karya Ayu Utami. Dengan menggunakan pendekatan penelitian kualitatif serta teori-teori sosiologi sastra, artikel ini menemukan bahwa citra perempuan sebelum dan sesudah Era Reformasi di Indonesia digambarkan secara berbeda. Sebelum Era Reformasi, citra perempuan cenderung patuh dalam menghadapi

\footnotetext{
*Corresponding Author: Wajiran Wajiran (wajiran@enlitera.uad.ac.id), Jl. Ringroad Selatan, Kragilan, Bantul, Daerah Istimewa Yogyakarta, Indonesia 55191
}

ISSN 0852-7172 (p) 2461-064X (e)

(C) 2020 by the Authors, published by Walisongo: Jurnal Penelitian Sosial Keagamaan https://journal.walisongo.ac.id/index.php/walisongo 
dinamika sosial-politik, sedangkan setelah Era Reformasi 1998, mereka digambarkan sangat progresif bahkan pemberontak. Namun, perbedaan citra perempuan sebelum dan sesudah reformasi tersebut juga menunjukkan kecenderungan politis dan ideologis sang penulis dalam menggambarkan posisi perempuan di tengah-tengah masyarakat pada zamannya. Temuan penelitian ini mendukung gagasan Gramsci tentang hegemoni ideologi atau budaya yang ada di dalam karya sastra.

Keywords: the image of women; Indonesian literature, reflection; reformation era, society; socio-political dynamic

\section{Introduction}

Every civilization has various perceptions toward women. Most of them regard that being a woman is unlucky. Many social scientists and philosophers such as Aristotle, St. Thomas Aquinas, and Plato believe that women are the weak creature. Therefore, women are unlucky, they are full of weaknesses and unrespected (Selden, 1985, p. 128). Philosophers assume that women's physical and psychological condition makes them have low quality than men. This inappropriate perception makes women have unsafe in the social and political position. Women are regarded as second-class people.

Because of the negative stigma, women cannot participate in the public sphere. Their activities are very limited to domestic jobs. Women were not allowed to participate in the political and social sphere (Norquay \& Park, 2006). As a result, they could not participate in taking the decision dealing with their society (interest), such as taking a part in a general election and so on. As a consequence, what was produced in the social and political arena always benefits men but not women. Women are always placed as an object of the social policy rather than the subject. Although the situation has changed, the stigma of women's inferiority still can be found in society.

This paper tries to describe women's social and political dynamic in Indonesia. The discussion will be based on the literature writing, especially written after the reformation era (Era Reformasi). After the reformation 
era, there were many new perspectives about female characters in Indonesian literature. Therefore, this paper will be more focused on how the writers present the image of women as the main character. How writers depict female characters in their social and political position. Is there any difference between a male and female writer in presenting about women?

This paper applies the qualitative research method. The main data are taken from novels as the object of this research. The data are in the form of quotation that reflects the ideas dealing with women's issues or image. The data were analyzed applying the sociological theory of literature, which meant that the reflection of literature presents what is occurring in society. To support the analysis, this paper also gathers the data from other resources such as books, journal articles, and research papers, such as the thesis.

Some previous researches deal with the image of women in Indonesian literature but they do not deal with the difference between male and female writers' points of view. Herry Aveling writes the first paper entitled Indonesian Literature after Reformasi: The Tongues of Women (2007). This paper asserts that female writers' existence brings good news for women. Female writers will bring women's voices, that represent the women's social and political interests (Aveling, 2007).

The second publication is written by Diah Ariani Arimbi, Reading Contemporary Indonesian Muslim Women Writers: Representation, Identity and Religion of Muslim Women In Indonesian Fiction (2009). This book is not so different from Aveling's ideas, yet it focuses on the issues of ideology brought by the female writers and their identity as female writers. The existence of female writers is believed to support the ideology which will give 'benefit' for women. Therefore, the existence of female writers will defend women's political interests.

Meanwhile, Barbara Hatley also writes an article entitled New Direction in Indonesian Women's Writing? The Novel Saman (1999). This paper is a response to the competition held by Jakarta Arts Council which 
gives the best appreciation to Ayu Utamis's novel, Saman (1998). This paper deal with the reason why this novel gets the best nomination. As mentioned by Hatley, this novel is regarded as bringing new perspectives in presenting female characters. Before the reformation era, female writers present the female character as obedient as a member of society, but Saman presents different views, the female character is depicted as a woman who wants to be free and have a personal choice. Besides, this novel presents female characters who want to run away from the social norms.

Wajiran (2020) in his Ph.D. thesis titled Images of Muslim Women in Contemporary Indonesian Literature, focuses on how Muslim writers present female characters in their works (Wajiran, 2020). The thesis deals with the difference between male and female writers in presenting female characters, especially those called the writer Period of 2000 (Sastrawan Angkatan Reformasi). Wajiran (2019), in his article Male's Perspective on Women in Contemporary Indonesian Literature, focuses only on how male writers depict female characters in their writing. This paper focuses on Muslim male writers: Habiburrahman El Shirazy dan Wahid Hasyim. Both writers are Muslim and activists in Islamic organizations; El Shirazy in FLP (Forum Lingkar Pena [Pen Circle Forum]), while Hasyim in Muhammadiyah.

From the previous publications, this paper presents different perspectives. This paper compares male and female writers' points of view toward women. Besides that, this paper also compares the ways of depicting women in Indonesian literature. Therefore, we choose two writers whose works are contradictive; Bekisar Merah (Tohari, 2005) represents patriarchy's ideology, while Saman (Utami, 1998) represents the ideology of feminism.

\section{The Flourish of Literary Works after Reformation Era}

The downfall of the Soeharto regime marked the beginning of freedom of expression in all aspects, especially in the writing tradition. Since then, lots of writers came to the surface such as from LEKRA: Lembaga Kebudayaan Rakyat (People's Cultural Institute). Ayu Utami, one of the 
women writers, hoisted sex scented literature through Saman. Then, in 2001, the award Equatorial Literary Award was given to writers who wrote the best novels. Those who have received this award were Goenawan Muhammad, Remy Sylado, Hamsad Rangkuti, Seno Gumira Ajidarma, Linda Christanty, Sapardi Djoko Damono, Joko Pinurbo, Gus TF., and Acep Zamzam Noor. In 2002, Horizon was published. It consists of four books including poetry, short stories, novels, and plays. In this book, Hamzah Fansuri who lived in the $17^{\text {th }}$ century was the first Indonesian writer.

Then, in 2003, Sapardi Djoko Damono and Ignas Kleden were awarded Ahmad Bakrie Award for their services in the field of literature. Writers and intellectuals who received the same award in subsequent years were Goenawan, Nurcholish Madjid, Budi Darma, Sartono Kartodirdjo. Frans Magnis Soeseno who should get the award Bakrie company refused because of the relationship with the Lapindo mudflow disaster in Sidoarjo, East Java. In 2004, literature on the internet is a breakthrough for writers to freely express and publish their work. Novel Ayat-Ayat Cinta by Habiburrahman El Shirazy was published in 2004. In the following year, 2005, the novel Laskar Pelangi by Andrea Hirata was also published. Laskar Pelangi and Ayat-Ayat Cinta became the best-seller novels in Indonesia's history of novel publishing. Both novels were then filmed (Rampan, 2000). There were also some re-publications of forbidden books written by Pramudya Ananta Toer, Tempo magazine, and many others.

Thus, the reformation era has brought a fresh air for women to voice their thoughts (Arimbi, 2009; Aveling, 2007). At this time, many women writers were born and coloured literary work such as Oka Rusmini (Sagra, 2002), Djenar Maesa Ayu (Mereka Bilang Saya Monyet, 2002; Jangan Main-main dengan Kelaminmu, 2004), Intan Paramadhita (Sibir Perempuan, 2005), Nukila Amal (Laluba, 2005), Weka Gunawan (Merpati di Trafalgar Square, 2004), Labibah Zain (addicted to weblog: Kisah Perempuan dalam Dunia Maya, 2005), Ucu Agustin (Kanakar: Kumpulan Cerpen Ucu Agustin, 2005), Evi Idawati (Malam Perkawinan, 2005). These writers seemed to follow the footsteps of their senior like 
NH Dini, Titis Basino, Leila S. Chudori, Ratna Indraswari Ibrahim or Abidah El-Khalieqy.

The above condition was much different from the previous regimes, Old Order and New Order. During the Old Order era, women's role was still alarming as they did not have the bargaining power compared to men. At that time, many women did not have the same rights in the public arena. Women during the Old Order were still regarded as the second class. Practices of polygamy were still rampant in society.

Meanwhile, the New Order regime also did not offer a better position for women. They were still controlled to support the interests of men. Women's movement was also restricted. It was caused by the presence of control and prohibition of some activities that would disturb public order or ideological threat, especially communism. New Order government through the Directorate of Culture supervised, assessed, and controlled every cultural activity, including women's activities (Jones, 2012).

\section{Male and Female Writers Tendency in the Novels}

Before the reformation era in 1998, literary works were dominated by male writers. Some male writers deal with women as the main character. Their works still supported men's interest or men's domination of women. According to Hellwig (1994), literature that male writes does not spread the ideology of patriarchy, but it confirms the domination of males toward women in society (Mohd, 2006). As a result, male author writing will be beneficial for men.

Hellwig inserts that the different point of view between men and women confirms that men have a special position in Javanese culture (Hellwig, 2012). This situation is legitimated by the values of religion and local customs that do not support women's emancipation in the public sphere. Women have a 'special period: menstruation, giving birth, and breastfeeding confirm that women's position is weak. In this period, women experience physical weakness therefore they have a low quality of life. Women in this period are regarded as unproductive human beings. 
Based on the situation above, is there any correlation between psychological condition with the literature that she produces? Or the literature written by female writers is an expression of dissatisfaction with the un-beneficial condition in their society? Is that true that female literature is only an emotional expression therefore their works have low quality?

The characteristic of the female writer becomes so versatile. The difference is on the theme and word choice in their literature. After the reformation era, the theme of sex and women's bodies are the two dominant themes for female writers. The vulgar word choice also marks this in literature. Some critics assume that this expression is caused by women's disappointment. In other words, female writers want to show that they do not want to be subordinate in their socio-political position. They want to escape from the confine of the men. Women's position as second-class people makes them experience unhappy-treatment in the social sphere.

According to Herry Aveling (2007), the existence of female literature after the reformation era makes it possible for everybody to listen to her voices. Female literary work is an expression of women's true soul. They represent the dream, ideas, and hope of women. This is because, in the previous era, literary works that presented women are commonly based on the male's perspective (Wajiran, 2019). Aveling asserted that some literature that deals with women's issues did not represent women's idealism. As can be seen in Siti Nurbaya (1921) by Marah Rusli, Layar Terkembang (1936) by Sutan Takdir Alisjahbana, Belenggu (1941) by Armijn Pane, Gadis Pantai (1987) by Pramudia Ananta Toer and Bekisar Merah (2005) by Ahmad Tohari.

According to Aveling, male literature that deals with women's issues still tells the real condition that happens in society. The female characters are still regarded as subordinate people. Women's existence is regarded only as the supplement of men to get their success. Sofi's (2018) work on Pramoedya A. Toer's Gadis Pantai, for instance, examines the complexity 
of political forces that shape female identity at the beginning of 20th century Java. His work found that women were doubly discriminated; they find themselves subject to higher powers, i.e. the powers of the local lord and the male. Because of that, women have very limited space to do and to speak. Women's existence is to support men's success and help men's job, giving birth to their children, keeping the children and the households, and keeping the community (Aveling, 2007). Therefore, it confirms the inferiority of women in social and political dynamics.

Hellwig affirms that male writers' work confirms the social tradition placed women as an object, not as a subject. Novel Ronggeng Dukuh Paruh for instance describes how the term "open the curtain" (bukak kelambu) illustrates how women are controlled and managed by men. Men have the dominant and higher position or authority toward women. The novel's main character illustrates that women are just the object of men's wishes and authority. Women can be bartered, sold, and exploited. This is also seen from the government rule in the New Order regime that places women as the subordinate. The New Order regime established the institution special for women to control their activity such as Panca Dharma Wanita (the Five Women's Principle), Pembinaan Kesejabteraan Keluarga (the Family Welfare Development), and Dharma Wanita (the wife organization of the government officials) (Mohd, 2006).

To see the difference between male and female writers in presenting their ideas about women's image, this following chapter presents two writers: Ahmad Thohari and Ayu Utami. The reason for choosing these two writers is because both are famous writers. Ahmad Thohari represents a male writer, while Ayu Utami represents a contemporary female writer.

\section{The Female Characters in Bekisar Merab by Ahmad Thohari}

The novel Bekisar Merah is one example of the women's position based on the male's perspective. This novel is written by Ahmad Thohari a productive writer whose writing is based on Javanese culture. He can be categorized as the old generation. He was born on June 13, 1948. Bekisar 
Merah was firstly published in a daily newspaper, Kompas, from February to May 1993. Then, it was published in a book in 2005. Even though it was written in the 1990s, but the theme is still relevant to the contemporary issues about women's social and political condition in Indonesia. This novel represents Javanese social and cultural dynamics. Therefore, this novel is regarded as representing males' perception of women reflected in literary work.

It is possible to assume that literature's subjectivity is very dominant in this novel. The writer's background of social, political, and ideological influence the writer in presenting the issue of women. The political interest of the writer is also important. As a result, the male writer will support and give benefits to men, while female writers will also give an opinion based on their interests.

Bekisar Merah contradicts modern women's social and political idealism because the female character's position is very weak. It can be assumed that the main character is placed as the second-class people in society and the family. Women are regarded as weak creatures not only in physic but also in economic, social, and psychology. As a result, the main character of the novel presents that the main character has no social and political bargaining dealing with her problem. The main (female) character becomes the victim of men's domination. The issue that occurs to the main character, Lasi represents the social attitude toward women in Javanese culture.

Lasi is a poor young woman who lives in a village, Karangsoga. The setting of the village in this novel indicates that a woman who is from a village is associated with ignorance and poverty.

Besides as a poor girl, she is not originally Javanese, because she has Japanese blood from her father. Lasi becomes the object of racism because of her father who is not Javanese. Every people in the village knows that she was born unwanted because her mother becomes the victim of sexual abuse by Japanese troops. Therefore, she is called anak Jadah or Haram child (illegitimate child). Because of that, even she is very beautiful, no one 
of the Javanese men wants to be her husband. Every young man who knows her family background does not want to marry her. This is caused by the negative stigmatization that illegitimate children. It is believed that illegitimate children will bring bad fortune in their lives. This situation makes Lasi gets difficulty getting married. As a result, her mother asks Darsa, the village's poor young man to marry her (Tohari, 2005, p. 40).

Darsa is a young man who lives in the village and works as a coconut picker. He is poor and has no social position. He is the only young boy who stays in his village because of his economic difficulty. He has no capital to go to the big city to find a better job. Besides that, he is also not enough educational background to work in a big city.

After getting married, both Lasi and Darsa have no better economic condition. They still live-in poor conditions because they have no skill to make their lives better. Nevertheless, the family's economic condition becomes worse when Darsa got into an accident. Darsa falls from a coconut tree when he was working. He hurt and his body is broken. Darsa cannot work to earn money for his family, therefore Lasi has to work for herself. Lasi works to get money and also to cure her husband. The limited money makes the family becomes so difficult. Lasi must borrow some money from a rich man in the village.

The poorness makes Lasi's life so difficult. She must borrow some money from Mr. Tir to cure her husband's illness. Mr. Tir is Kanjat's father. Kanjat is a university student who has a feeling of love for Lasi.

Lasi has no other choice, therefore she asked a soothsayer to cure her husband. The soothsayer's name is Bunek. In the beginning, Bunek always comes to Lasi's house to cure Darsa's health problems. Nevertheless, after Darsa's illness is getting better, Bunek asked Darsa to come to her house. Unfortunately, after Darsa looks better, Bunek asks Darsa to sleep with her daughter. In the end, Bunek's daughter getting pregnant. It means that the curing process is successful (Tohari, 2005, p. 62).

The story becomes so complicated after Bunek's daughter, Sipah is pregnant by Darsa. Sipah is mentally ill. She has old enough without a 
husband. This condition is used by Bunek to encourage Darsa to marry her. Because of Sipah's pregnancy, Lasi's marriage is broken. Lasi's life becomes so worse. Lasi must share her husband with other women. This situation makes her life becomes so complicated and frustrated. She should accept Sipah as the second wife of Darsa.

Lasi decides to go out from her village. She runs away to Jakarta. She met seorang germo (pimp) in Jakarta and stayed there for several days. At the first, she lives with Mrs. Koneng, whose house becomes the food store in which Pardi and Sopan (Mr. Tir's truck driver) always visit. After several days, Lasi was asked to live with Mrs. Lanting. She is a professional pimp, who always finds girls for a rich man to get a second wife. Mrs. Lanting treated Lasi very well, therefore Lasi does not know that Mrs. Lanting wants her to get married to a rich old man. Mrs. Lanting treats Lasi as if she is her daughter. She does it because Mrs. Lanting will get good tips (salary) from the rich man. Lasi is an excellent girl for the rich old man. Mr. Handarbeni is the lucky rich old man who gets the chance to marry Lasi.

After they marry, Lasi is unhappy. Although she gets many 'benefits' in that marriage, such as wealth and good social status but that cannot help her to be happy. Her husband, Mr. Handarbeni cannot give her sexual happiness which makes her very frustrated. This condition makes her life in very poor condition. Ironically, Mrs. Lanting advises her unbelievable solution. She told her to find another man to have sexual happiness. This is the false principle that is done by many women who are in a frustrating situation. They do it even their conduct contradicts the social norms.

Lasi has no power to go out from her problem in this difficult situation. Everything depends on her society and the society will depend on men's decisions. As a result, this situation makes her more difficult to get out of her own decision. Her problem can be only solved if she has the "perfect" man in her life. Even though she gets good social status and wealth, they are in her husband's name not because of herself. Lasi is under the control of her husband. Lasi has no power in social, economic, 
and political bargaining. Her activities must be authorized and approved by society and her husband. If she does something that contradicts the social norms she will be in big problems.

\section{The Female Character in Saman by Ayu Utami}

Ayu Utami is regarded as the pioneer in the freedom of expression in literature. She wrote about sensitive issues that encourage the contradictive opinion from critics. Her works that deal with women's bodies and sexual freedom are 'unusual' in the Indonesian context. These themes were regarded as forbidden and taboo in New Order and the Old Oder regime. Thus, Ayu Utami's work is regarded as the progressive literature in women's social and political dynamics (Nurhadi, 2007). If we see the work of Ayu Utami, we will find that the ideological issue that is reflected in her work is a kind of rebellion, the rebellion against social and religious norms and moral values. It is because, sexuality, women's body, or erotism is private matters that cannot be discussed in the public sphere.

Ayu's famous work is Saman. It is her first novel and got good responses from critics and readers. This novel gained awards not only in Indonesia but also in Western countries. One of the prominent awards was nominated by Prince Clause in 2000. Previously, this novel also got an award from the Jakarta Art Council (Dewan Kesenian Jakarta) in 1998.

Besides getting appreciation from critics, this novel is also criticized by many people. The criticism is caused by the vulgarity of the language of the novel. The novel presents sexual activity and women's body very open. In Javanese, especially in Islam, these themes are regarded taboo in the public sphere. Sexual activity is very personal. Therefore, many Muslim scholars do not respect this novel. For example, Taufik Ismail says that this kind of novel is not appropriate for Indonesian especially Muslims (see Wajiran, 2018).

The description of a female character in Saman has a different perspective from Bekisar Merah. This is caused by the writer's worldview that makes it different. Ayu Utami represents the female's perspective, 
while Ahmad Tohari represents the male's worldview. In Saman, the main character is depicted as a stronger and independent woman, while in Bekisar Merah the female character is very weak. In Ayu Utami's novel, women have their freedom. The female character is depicted very strong in keeping the personal principle therefore they are tough in facing life problems. The domination of men toward women is very weak in Saman and Larung. Furthermore, female characters in Ayu Utami can be called more than independence, they try to rebel against men's domination in the social and political sphere.

Saman can be interpreted as an expression of disappointment because of the women's unbeneficial situation. The limitation of women's activity and speech is the reason why women have not a good position in social and political spheres. In the reason of morality and religious values, women are limited to do and speak. This condition makes them subordinate. The upset expression can be interpreted from the word choice and the expression of the character that seems too expressive in dealing with women's freedom. An example of this issue can be seen at the beginning of the novel. It shows how to be an independent human being like the free bird. The word order and word choice determined and influential to readers.

The word choice presented in the beginning chapter is reflected in the following chapter. The word 'freedom' is reflected in the main character "I" in the novel. The main character is a woman who has freedom of thought and expression in her life. Therefore, she chooses to do a free relationship with the male character, Sihar. She chooses New York City as the setting to represent a free place for the action of free sex. In this city, no one cares about others, dealing freedom of sex. There will be no one who cares about their activity. They can forget the family, child, father, mother, and society will not know what they are doing (Saman: 28).

Ayu Utami describes sexual activities in a vulgar way. Without using personification or illustration. This way is unusual and very immoral based on eastern moral values especially Islamic moral values. The way of telling 
the sexual activity is inhuman and unacceptable for Indonesian society. This way is very rare to be found in Javanese culture or Indonesia in the Old Order and New Order regime. The male writers commonly use personification in dealing with sexual activity in their literature. Because of this way, Ayu Utami is regarded as the female writer who rebels against the social and religious norm in the Indonesian context.

The way of the depiction in Saman contradicts with the eastern culture that respects morality or ethical values. Furthermore, many Muslim critics regard this novel encourages teenagers to do free sex without marriage. As Taufiq Ismail, a famous Muslim poet called this kind of literature "fragrant literature" or groin literature (see in Marching, 2007). The freedom of expression contradicts religious or social norms in Indonesia. Therefore, this novel is regarded as dangerous reading material for the young generation in Indonesia.

The depiction of the female characters in Saman is more progressive or even be called rebellious characters. This can be seen from how the female character is depicted as having freedom and un-controllable in her life. She lives with her own free-life choice. Therefore, this is an indication that the writer wants to show how women should be in her life. This depiction can be interpreted as the author's strategy to get 'special' attention from readers. Therefore, what is intended by the author comes true when her novel becomes very controversial in society. Many readers give responses to the novel; some support the idea of the female character and some reject it as a part of good literary work.

This way of depiction is very different from that of Tohari. The female character in Bekisar Merab looks very dependent on society. The female character always tries to follow the social norm although sometimes she faces some difficulties in her own life. In Bekisar Merah the female character cannot choose her own life decision. This way of depiction can be interpreted that the male author put the female character to follow the social norm which is determined by men. In general, the leader of Javanese society from the village to the big city was led by men. 


\section{Conclusion}

This discussion leads us to know that there are differences between male and female writers in depicting female characters in literature. This is an important clue that the different perspective causes the difference in seeing the issue. This difference can also be a sign that the writer's political and ideological interest in describing the main characters.

Discourse in literature is very important in gaining the opinion of the readers therefore literature has a good position as the media of transformation. The discourse that is presented in the literature will influence society. Therefore, it is important to see the problem from both sides dealing with women's issues, from male and female writers. This way of seeing an issue, especially about the women's social and political position will be very important to be a wise decision. This way will make our decision fair and acceptable in the modern social context.

However, from this point of view, we can see that what is described by male writers is just the reflection of what is happening in society. On the other hand, the female writer looks like an ideal about the women's position in Indonesian society. What is reflected in women's novels is not the real condition that happens in Indonesia but it still the new discourse that is proposed by women to change their condition in Indonesian society. However, it can be concluded that Ayu Utama presents more progressive and even rebellious female characters than Ahmad Thohari.

Based on what has been discussed above, we can conclude that literary work is influenced by the social and political conditions of society. As a part of society, a writer tries to follow the trend or the suitable situation that supports his/her ideas. Furthermore, the worldview about women also much influenced by the socio-political situation whereby the writer wants to express his or her opinion or expression.

The intention of the writer in expressing his/her opinion also can be part of propaganda. Suppose the author has an affiliation with a specific social organization or a political party. In that case, the writer should bring the idea based on the interest of his/her community or ideology. In 
the Indonesian context, can be seen in the case of LEKRA: Lembaga Kebudayaan Rayat --the Institute of People's Culture, the cultural wing of the Indonesian Communist Party (PKI)-- which member are the writers who bring the ideology of communism in their works. This case also the same as what is happening in Islam. Many writers who are joining the FLP (Forum Lingkar Pena, Pens Circle Forum) bring Islamic moral values as their foundation.[w]

\section{References}

Arimbi, D. A. (2009). Reading Contemporary Indonesian Muslim Women Writers: Representation, Identity and Religion of Muslim Women in Indonesian Fiction. Amsterdam: Amsterdam University Press. https://doi.org/10.5117/9789089640895

Aveling, H. (2007). Indonesian Literature after Reformasi: The Tongues of Women. Kritika Kultura, 8, 5-26. https://doi.org/10.13185/1524

Hatley, B. (1999). New directions in Indonesian women's writing? The novel Saman. Asian Studies Review, 23(4), 449-460. https://doi. org/10.1080/10357829908713250

Hellwig, T. (1994). In the Shadow of Change [Images of] Women in Indonesian Literature. Berkeley: Centers for South and Southeast Asia Studies University of California.

Hellwig, T. (2012). Women and Malay Voices Undercurrent Murmurings in Indonesia's Colonial Past. New York: Peter Lang.

Jones, T. (2012). Indonesian Cultural Policy in the Reform Era. Indonesia, 93, 147-176. https://doi.org/10.5728/indonesia.93.0147

Marching, S. T. (2007). The Representation of the Female Body in two Contemporary Indonesian Novels: Ayu Utami's Saman and Fira Basuki's Jendela-jendela. Indonesia and the Malay World, 35(102), 231-245. https://doi.org/10.1080/13639810701440699

Mohd, T. U. M. (2006). In the Shadow of Change [Images of] Women in Indonesian Literature oleh Tineke Hellwig: Ulasan Kritis. Sari: Jurnal Alam dan Tamadun Melayu, 24, 161-172.

Norquay, G., \& Park, S. S. (2006). Mediating women's suffrage literature. Women's Studies International Forum, 29(3), 301-306. https://doi. org/10.1016/j.wsif.2006.04.006 
Nurhadi, N. (2007). Dari Kartini hingga Ayu Utami; Memposisikan Penulis Perempuan dalam Sastra Indonesia. Diksi, 14(2), 155-165. https://doi.org/10.21831/diksi.v14i2.6597

Rampan, K. L. (2000). Angkatan 2000 dalam Sastra Indonesia. Jakarta: Grasindo.

Selden, R. (1985). A Reader's Guide to Contemporary Literary Theory. Bringhton: The Harvester Press Limited.

Sofi, M. J. (2018). Politics of Female Identity in Traditional Java through the Prism of Pramoedya A. Toer's Gadis Pantai. Walisongo: Jurnal Penelitian Sosial Keagamaan, 26(2), 345-364. https://doi.org/ 10.21580/ws.26.2.3181

Tohari, A. (2005). Bekisar Merah. Jakarta: Gramedia.

Utami, A. (1998). Saman. Jakarta: Kepustakaan Populer Gramedia.

Wajiran, W. (2018). Polygamy and Muslim Women in Contemporary Indonesian Literature. Jurnal Humaniora, 30(3), 291-304. https:// doi.org/10.22146/jh.34821

Wajiran, W. (2019). Male's Perspective on Women in Contemporary Indonesian Literature. Walisongo: Jurnal Penelitian Sosial Keagamaan, 27(2), 279-298. https://doi.org/10.21580/ws.27.2. 4384

Wajiran, W. (2020). Images of Women in Contemporary Indonesian Literature. University of Tasmania. 
The page was intentionally left blank. 